\title{
Simultaneity of unhealthy behaviors associated with hypertension among Brazilian adults
}

\author{
Simultaneidade de comportamentos não saudáveis associados à hipertensão em \\ adultos brasileiros
}

\section{AUTHOR'S \\ Priscila Cristina dos Santos $^{1}$ (D) \\ Giovani Firpo Del Duca ${ }^{1}$ (D) \\ Kelly Samara da Silva ${ }^{1}$ (D) \\ Rafael Martins da Costa ${ }^{1}$ (D) \\ Anne Ribeiro Streb ${ }^{1}$ (D) \\ Aline Mendes Gerage ${ }^{1}$ (i) \\ Deborah Carvalho Malta ${ }^{2}$ \\ 1 Universidade Federal de Santa Catarina, \\ Departamento de Educação Física, Florianópolis, \\ Santa Catarina, Brasil. \\ 2 Universidade Federal de Minas Gerais, \\ Departamento de Enfermagem Materno Infantil e Saúde Pública, Belo Horizonte, Minas Gerais, Brasil}

\section{CORRESPONDING}

Priscila Cristina dos Santos

prisantos.personal@gmail.com

Campus Reitor João David Ferreira Lima, s/n, Trindade, Florianópolis, Santa Catarina, Brasil. CEP: 88040-900.

\section{DOI}

$10.12820 /$ rbafs. $24 \mathrm{e} 0100$

\section{(cc) BY-NC-SA}

This work is licensed under the Creative Commons Attribution-NonCommercial-ShareAlike 4.0 International License.

\begin{abstract}
It is well known that some unhealthy behaviors are potentially associated with hypertension, but it is not known which combinations of simultaneous behaviors increase the chance of developing hypertension. In addition, more evidence is needed to assist in the development of preventive public policies in low- and middle-income countries. Thus, the objective was to determine the association between the clustering of four unhealthy behaviors and the occurrence of hypertension among Brazilian adults. The secondary data analyzed are derived from VIGITEL 2015 database, a cross-sectional national surveillance that included 35,548 adults aged 18 to 59 years living in Brazilian state capitals. Unhealthy behaviors and hypertension were measured by self-report. Sixteen combinations based on the presence and absence of the four unhealthy behaviors were performed and binary logistic regression was used to determine the association between simultaneity of these behaviors and hypertension. The odds to have all unhealthy behaviors were 3.50 (95\%CI: $2.96-4.10)$ times higher than the expected value if unhealthy behaviors were independent. Adults with simultaneous all risk behaviors $(\mathrm{OR}=2.42 ; 95 \% \mathrm{CI}: 1.20-4.85)$, with excessive salt consumption and physical inactivity $(\mathrm{OR}=1.41 ; 95 \% \mathrm{CI}: 1.11-1.80)$ and with excessive alcohol consumption and physical inactivity $(\mathrm{OR}=1.60 ; 95 \% \mathrm{CI}: 1.14-2.25)$ were more likely to have hypertension compared to the people without unhealthy behaviors. In conclusion, some combinations of unhealthy behaviors were actually more dangerous for hypertension in the investigated population. Future public policies to prevent hypertension can be more effective if to focus on simultaneity of unhealthy behaviors that increased the chance of developing the disease, especially physical inactivity.
\end{abstract}

Keywords: Risk factors; Hypertension; Cross-sectional studies; Adults.

\section{RESUMO}

A associação existente entre alguns comportamentos não saudáveis e hipertensão está bem estabelecida na literatura, entretanto, ainda não está claro quais agrupamentos em especifico podem aumentar a chance de desenvolvimento da doença. Ademais, são necessárias mais evidências para auxiliar no desenvolvimento de politicas públicas preventivas em países de baixa e média renda. Assim, o objetivo do presente estudo foi investigar a associação entre os agrupamentos de quatro comportamentos não saudáveis e hipertensão em adultos brasileiros. Os dados analisados são derivados do banco de dados Vigitel 2015, uma pesquisa transversal que incluiu 35.548 adultos entre 18 e 59 anos residentes em capitais brasileiras. Os comportamentos não saudáveis e hipertensão foram medidos por meio de auto relato. Dezesseis combinaçôes baseadas na presença e ausência dos quatro comportamentos foram realizadas e para determinar a associação entre a simultaneidade desses comportamentos e hipertensão foi utilizada regressão logística binária. A chance de ter todos os comportamentos não saudáveis foi 3,50 (IC95\%: 2,96-4,10) vezes maior que o esperado se os comportamentos fossem independentes. Adultos com todos os comportamentos não saudáveis $(O R=2,42$; IC95\%: 1,20 - 4,85), com consumo excessivo de sal e inatividade física (OR =1,41; IC95\%: 1,11 - 1,80) e com consumo excessivo de álcool e inatividade física $(O R=1,60$; IC95\%: 1,14 - 2,25) apresentaram associação com hipertensão. Conclui-se que algumas combinações de comportamentos não saudáveis foram mais perigosas para o desenvolvimento da hipertensão na população investigada. Futuras políticas públicas focadas na prevenção dessa doença podem ser mais eficazes se considerarem os agrupamentos que aumentam a chance de desenvolver a hipertensão, principalmente a inatividade física.

Palavras-chave: Fatores de risco; Hipertensão; Estudos transversais; Adultos.

\section{Introduction}

Hypertension is an important risk factor for cardiac and cerebrovascular complications, being considered a public health problem ${ }^{1,2}$ and affects $30 \%$ to $45 \%$ of adults worldwide 3 . In 2015, for example, more than three-quarters of deaths caused by cardiovascular di- 
sease occurred in low and middle income countries ${ }^{4}$. Considering the increase in the number of people diagnosed with hypertension in low- and middle-income countries ${ }^{5}$ and the reduced opportunity for treatment when compared to high-income countries ${ }^{6,7}$, it is necessary to better understand the influence of the adoption of deleterious behaviors on the health of this population.

Besides the classical biological risk factors (i.e., age, sex, and ethnicity), some unhealthy behavioral (i.e., excess alcohol and salt, tobacco consumption and physical inactivity) are considered to be modifiable risk factors for the development and worsening of hypertension ${ }^{1,8}$. In fact, excess salt has been shown to be singly associated with increased blood pressure levels and with hypertension ${ }^{9}$, as observed for excessive alcohol consumption $^{10,11}$, tobacco use $e^{8,12}$ and physical inactivity ${ }^{8,13}$. The adoption of more than one of these behaviors is associated with early mortality ${ }^{14}$ and with an increased risk of developing hypertension ${ }^{15}$.

However, despite being well established in the literature that the increase in the number of unhealthy behaviors are associated with the greater chance of developing hypertension, it is unclear which combinations of these unhealthy behaviors are more harmful ${ }^{16}$. Thus, analyzing the co-occurrence of these behaviors may indicate potentially harmful combinations, as well as guide beneficial interventions for the prevention and treatment of hypertension. On this basis, the objective of the present study was to determine the association between clustering of four unhealthy behaviors and the occurrence of hypertension among Brazilian adults.

\section{Methods}

This cross-sectional study is derived from the system "Surveillance of risk behaviors and protection against chronic diseases by telephone survey (VIGITEL)", which has been organized since 2006 by the Ministry of Health. The data used in this study were obtained in 2014 and were published in a report in 2015. The target population of this study consisted only of Brazilian adults aged 18 to 59 years, living in the 27 Brazilian capitals and having a home telephone line.

In order to select the sample in a probabilistic way, the telephone lines were selected with the use of a systematic drawing of 5,000 telephone, stratified by Postal Code. The lines were divided into subsamples of 200 each, reproducing the same proportion by city region or telephone prefix. After the identification of the eligible lines, participants were randomly assigned to the interview. The estimates produced were adjusted to the Brazilian population using the post-stratification weight considering gender, age group, and years of study. The post-stratification weight of each individual in the sample was calculated by the rake method. The data were obtained with a questionnaire filled with simultaneous computer resources that are constantly being evaluat$\mathrm{ed}^{17}$. The details of the sampling plan and the application of weights are available in other publications ${ }^{18}$.

Informed consent was obtained in a verbal manner at the time of the telephone interview. Approval of the VIGITEL project was obtained from the National Research Ethics Committee, under number 355,590.

The diagnosis of hypertension was the dependent variable, consisting of an affirmative response to the question: "Did some doctor already tell you that you have high blood pressure?"

The independent variables were: 1) Tobacco use (“Do you currently smoke?"). A person who reported smoking at least one cigarette per day was considered a smoker; 2) Excessive use of salt ("Adding salt to a freshly prepared meal and eating processed foods, or how high do you think your salt intake is?"). Excessive salt consumption was considered when adults reported that their salt consumption was high or very high; 3 ) Excessive use of alcohol ("Do you usually drink alcohol?" and "How often do you usually drink alcohol?"). Excessive alcohol consumption was considered when adults reported that they consumed at least five or more doses (men) or four or more doses (women) on a single occasion. 4) Physical inactivity ("Over the last three months, did you practice any type of physical exercise?", "What is the main type of physical exercise or sport that you engage in at least once a week?", "How many days a week do you usually exercise or engage in a sport?", and "On the day that you practice exercise or a sport, how long does this activity last?"). Those who did not practice 150 minutes a week of moderate physical activity or at least 75 minutes a week of vigorous physical activity were considered to be physically inactive.

Adjustment variables were sex, age (continuous), years of study (three categories: 0 to 8; 9 to 11 and 12 or more years of study) and ethnicity (two categories: black and other ethnicities).

For descriptive analysis, relative and absolute frequency was determined considering a $95 \%$ confidence interval $(95 \% \mathrm{CI})$. The 16 combinations (considering the four unhealthy behaviors in a dichotomous way - 
yes and no) of behaviors were then examined in terms of their observed $(\mathrm{O})$ and expected $(\mathrm{E})$ prevalence and their respective $\mathrm{O} / \mathrm{E}$ ratio. The expected prevalence was calculated by multiplying the individual probabilities of each behavior in the population studied.

The association between the clustering of behaviors with hypertension was determined by binary logistic regression. The $\mathrm{p}$-values $<0.05$ were considered statistically significant and the results are expressed as odds ratios (OR) with 95\%CI. The models were adjusted by sex, age, years of study and ethnicity. Data were analyzed using the svy command of the Stata software, version 13.0, which applies the weighting factors of complex sampling through the rake method. It was necessary for the present study due to the sampling process used, in which part of the individuals is not likely to be selected for the sample. This procedure used variables available in the sample and in the population, obtained from external sources, to adjust the sample distribution ${ }^{19}$.

\section{Results}

Of the 54,174 participants, 35,548 were adults (65.4\%), $59.4 \%$ were women and $19.2 \%$ self-kdeclared black ethnicity. In relation to unhealthy behaviors, $10.7 \%$ reported consuming tobacco, $16.7 \%$ consumed alcohol in excess, $19.5 \%$ salt in excess and $59.9 \%$ reported being physically inactive during leisure time. The percentage of adults diagnosed with hypertension was $18.5 \%$ (Table 1).

According to the results shown in Table 2, among the unhealthy behaviors investigated, only physical inactivity was associated with hypertension $(\mathrm{OR}=1.38$; 95\%CI: 1.21 - 1.58).

Table 3 shows the prevalence of 16 different possible combinations among tobacco use, excessive salt consumption, excessive alcohol consumption and physical inactivity in the present sample. Physical inactivity was the more frequent risk behavior isolated (38.2\%), followed by the clustering of absence of all unhealthy behaviors (25.1\%), and the clustering of presence of excessive salt consumption in combination with physical inactivity (7.22\%). According to the number of cases observed and expected of the 16 possible combinations, the simultaneity of all unhealthy behaviors was 3.50 times higher than the expected value if these behaviors or combinations were independent. A ratio of 2.90 was observed for the clustering of tobacco use, excessive salt consumption and excessive alcohol con-
Table 1 - Socio-demographic characteristics and unhealthy behaviors in Brazilian adults ( $\mathrm{n}=35,448) .2014$.

\begin{tabular}{|c|c|c|c|}
\hline Variables & $\mathrm{n}$ & $\%$ & $95 \% \mathrm{CI}$ \\
\hline \multicolumn{4}{|l|}{ Sex } \\
\hline Male & 14,379 & 47.4 & $(46.3-48.5)$ \\
\hline Female & 21,069 & 52.6 & $(51.5-53.7)$ \\
\hline \multicolumn{4}{|l|}{ Ethnicity } \\
\hline Black & 9,781 & 19.2 & $(18.4-19.9)$ \\
\hline Other ethnicities & 43,246 & 80.8 & $(80.0-81.5)$ \\
\hline \multicolumn{4}{|l|}{ Years of study } \\
\hline 0 a 8 & 6,323 & 28.5 & $(27.4-29.6)$ \\
\hline 9 a 11 & 14,495 & 42.1 & $(41.0-43.1)$ \\
\hline$\geq 12$ & 14,630 & 29.4 & $(28.5-30.3)$ \\
\hline \multicolumn{4}{|l|}{ Tabacco consumption } \\
\hline Yes & 2,849 & 10.6 & $(9.9-11.4)$ \\
\hline No & 32,599 & 89.3 & $(88.5-90.0)$ \\
\hline \multicolumn{4}{|c|}{ Excessive salt consumption } \\
\hline Yes & 5,486 & 16.6 & $(15.9-17.5)$ \\
\hline No & 29,962 & 83.4 & $(82.5-84.1)$ \\
\hline \multicolumn{4}{|c|}{ Excessive alcohol consumption } \\
\hline Yes & 6,097 & 19.4 & $(18.6-20.3)$ \\
\hline No & 29,351 & 80.6 & $(79.6-81.4)$ \\
\hline \multicolumn{4}{|l|}{ Physical inactivity } \\
\hline Yes & 20,445 & 59.9 & $(58.1-60.9)$ \\
\hline No & 15,003 & 40.1 & $(39.1-41.2)$ \\
\hline \multicolumn{4}{|l|}{ Hypertension } \\
\hline Yes & 7,373 & 18.5 & $(17.6-19.4)$ \\
\hline No & 28,029 & 81.5 & $(80.6-82.3)$ \\
\hline
\end{tabular}

Table 2 - Association of each unhealthy behaviors with hypertension in the Brazilian adults. 2014.

\begin{tabular}{lcccc}
\hline \multirow{2}{*}{ Unhealth behaviors } & \multicolumn{2}{c}{ Crude } & \multicolumn{2}{c}{ Adjusted } \\
\cline { 2 - 5 } & OR & $95 \% \mathrm{CI}$ & OR & $95 \% \mathrm{CI}$ \\
\hline Tobacco use & 1.17 & $0.96-1.44$ & 0.99 & $0.81-1.21$ \\
$\begin{array}{l}\text { Excessive salt } \\
\text { consumption }\end{array}$ & 0.95 & $0.82-1.10$ & 1.02 & $0.89-1.19$ \\
$\begin{array}{l}\text { Excessive alcohol } \\
\text { consumption }\end{array}$ & 0.86 & $0.74-1.01$ & 0.97 & $0.83-1.14$ \\
\begin{tabular}{l} 
Physical Inactivity \\
\hline
\end{tabular} & 1.65 & $1.46-1.87^{*}$ & 1.38 & $1.21-1.58^{*}$ \\
\hline
\end{tabular}

Note: The model was adjusted for sex, age, years of study and ethnicity. *represents a statistically significant result.

sumption, and a ratio of 2.18 for the combination of tobacco use, excessive alcohol consumption and physical inactivity.

All co-occurrence that showed an association with hypertension had physical inactivity among unhealthy behaviors. Adults in clustering characterized with excessive salt consumption and physical inactivity $(\mathrm{OR}=$ 1.41; 95\%CI: 1.11 - 1.80), excessive alcohol consumption and physical inactivity $(\mathrm{OR}=1.60 ; 95 \% \mathrm{CI}: 1.14$ - 2.25), and with all unhealthy behaviors $(\mathrm{OR}=2.42$; 
Table 3 - Simultaneity and association between clusters of unhealthy behaviors for hypertension in the Brazilian adults. Observed and expected percentage and its odds ratio with 95\% confidence interval. 2014.

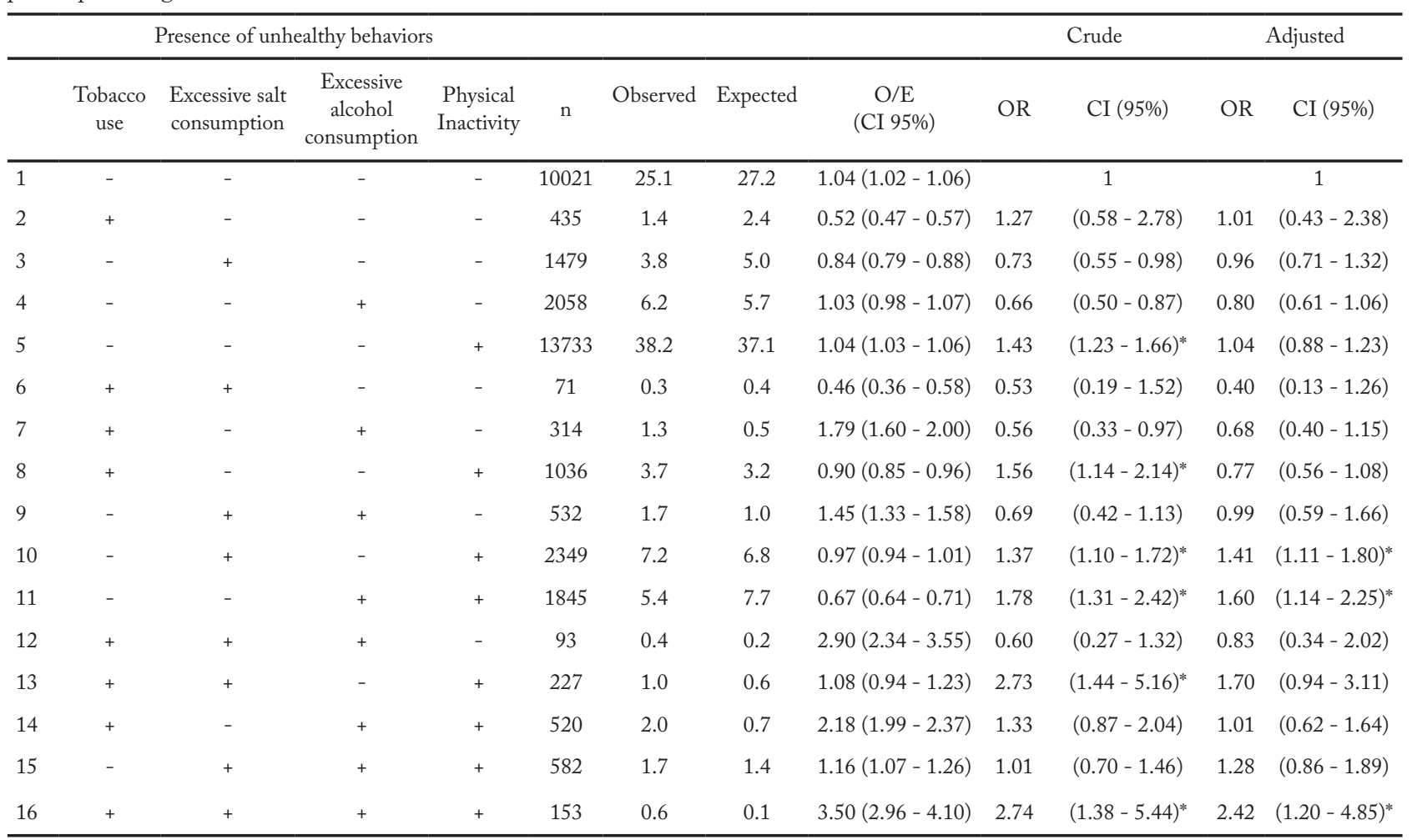

Note: + = presence of unhealthy behaviors. - = absence of unhealthy behaviors. $\mathrm{O} / \mathrm{E}=\%$ observed $/ \%$ expected. The model was adjusted for sex, age, years of study and ethnicity. *represents a statistically significant result.

95\%CI: $1.20-4.85)$ were more likely to have hypertension (Table 3).

\section{Discussion}

This study analyzed the simultaneity of tobacco use, excessive salt consumption, excessive alcohol consumption and physical inactivity, as well as its association with hypertension among Brazilian adults. The main results were the identification of some clustering of specific unhealthy behaviors associated with hypertension. In addition, we emphasize that physical inactivity is an important risk factor for hypertension, since it was present in all clustering associated with this disease. Even so, it is worth highlighting the contribution of other unhealthy behaviors to the worsening of health status and increased risk of hypertension.

It is well established that hypertension is one of the major public health issues ${ }^{20}$. Globally, cardiovascular disease accounts for approximately 17 million deaths a year, nearly one third of the total. Moreover, complications of hypertension account for 9.4 million deaths worldwide every year ${ }^{20}$. In the present study, the prevalence of hypertension was $18.5 \%$ among Bra- zilian adults, which may present an underestimated prevalence because our variable represents only those people who had a medical diagnosis of the disease. In 2010, the hypertension prevalence in adults and elderly in high- and low/middle-income countries was $28.5 \%$ and $31.5 \%$ respectively ${ }^{6}$. Besides the higher proportion of the hypertension among low- and middle-income countries, it was observed from an analysis of ninety countries that population awareness and treatment opportunities are much higher in high-income countries $^{6}$. These global disparities in hypertension are large and growing, highlighting the need for specifics studies and public policies for these countries ${ }^{6,7}$.

According to the results of the isolated unhealthy behaviors, only physical inactivity was associated with hypertension. The physical inactivity corresponds to $6 \%$ of the negative charge for heart disease worldwide ${ }^{21}$. Further, it has a major impact on chronic non-communicable diseases when only one risky behavior is analyz$\mathrm{ed}^{21}$. However, the occurrence of one unhealthy behavior is usually accompanied by other unhealthy behaviors ${ }^{16}$.

It was observed that all unhealthy behaviors tended to be more clustered than expected if these behaviors 
or their combinations were independent $(\mathrm{OR}=3.50$; 95\%CI: 2.96 - 4.10). These findings are similar to those reported for Netherlands ${ }^{22}$ and England ${ }^{23}$ adults, where the observed prevalence was $170 \%$ and $200 \%$ higher than expected, respectively, if the four unhealthy behaviors were independent. This result draws attention to the fact that risk behaviors tend to cluster and not occur in isolation. In addition, most of the adults in the present study were physically inactive (33.8\%) without showing other unhealthy behavior. In contrast, a systematic review focusing on the co-occurrence or clustering of two or more unhealthy behaviors in England found that alcohol misuse and smoking were the most commonly identified unhealthy behaviors cluster among adults ${ }^{24}$. In European countries, for example, smoking is very common, while in Brazil the prevalence is low due to awareness elicited by public actions ${ }^{25}$. Thus, the clustering of unhealthy behaviors seems to depend on some factors such as socioeconomic status, culture and level of development of the country ${ }^{24,26,27}$.

Besides, the clustered characteristics in the present Brazilian national sample, we also identified that some unhealthy behaviors increased the probability of the occurrence of hypertension. Regardless of age, sex, years of study or ethnicity, Brazilian adults in the cluster with excessive salt consumption and physical inactivity, in the cluster with excessive alcohol consumption and physical inactivity and in the cluster with all four unhealthy behaviors investigated were more likely to develop hypertension when compared to individuals who did not show any of these unhealthy behaviors. According to $\mathrm{Li}$ et al. ${ }^{28}$, the number of risk factors (smoking, alcohol drinking, low fruit and vegetables consumption, physical inactivity, and overweight or obesity) influenced the blood pressure levels in a large sample of Chinese adults. Other study, conducted on a representative sample of Japanese workers, observed that the risk of hypertension increased in a dose-dependent manner as the total number of cardiovascular risk factors increased (body mass index, levels of total cholesterol, triglycerides, fasting plasma glucose, uric acid, white blood cell count, family history of hypertension, and alcohol intake $)^{15}$. However, these studies did not explore which clusterings were associated with hypertension.

Knowing that these unhealthy behaviors can be modified, policy development should consider these behaviors simultaneously and not separately, as well as, to focusing on the highest-risk groups identified. Considering that public policies in low-and middle-in- come countries need to be better based on evidence and barriers to the implementation of these policies need to be overcome, our results can help to formulate more effective strategies and increase the body of evidence in the area ${ }^{29}$. It is also important to consider cultural and social differences that interfere with the clustering of unhealthy behaviors and, according to our findings, to give special attention to actions focused on the promotion of physical activity because the physical inactivity was a common risk behavior in all clusterings associated with hypertension. As highlighted in previous studies ${ }^{8,13,21}$, we emphasize the importance that physical activity has as a protective factor for hypertension also in Brazilian adults.

The present study has some strengths, such as monitoring health conditions in a representative sample of Brazilian adults and the association analysis of the possible combinations of unhealthy behaviors with hypertension. On the other hand, we could not extrapolate these results to Brazilian adults living outside the capitals of Brazil and to those without landline telephone coverage. The self-reporting of collected information should be analyzed with caution since it could generate bias related to insufficient reporting and/or socially desirable responses, especially in the case of excessive consumption of alcohol and the practice of physical activity (i.e. underestimation of excessive alcohol consumption and of physical inactivity). In addition, the instruments used may present a classification bias due to the weakness of the measure. Alcohol consumption, for example, does not reflect the chronic ingestion of the drink, but rather a recent behavior, present mainly in young adults with high income. The measure does not represent a chronic behavior and may confuse the association with hypertension, since the deleterious effects of excessive alcohol consumption appear over the years ${ }^{30}$. Another limitation is the possibility of reverse causality due to behavioral changes after the diagnosis of the disease, since the hypertension variable in the present study was measured considering a medical diagnosis and those individuals who know they have a health problem are more likely to take care of their health. For instance, some participants may have reduced salt intake due to the diagnosis of hypertension. We also emphasize that although years of study is a variable that can indicate socioeconomic status, it is only a proxy and does not reflect all dimensions of economic income.

In conclusion, the clustering of tobacco use, excessive salt intake, excessive alcohol consumption and 
physical inactivity, the clustering of excessive salt consumption and physical inactivity, and the clustering of excessive alcohol consumption and physical inactivity were associated with hypertension among Brazilian adults. Physical inactivity was the only behavior present in all clusters associated with hypertension. These results highlight the need for future interventions and public policies to be multicomponent with focus on the simultaneity of the unhealthy behaviors associated with hypertension for improving the control and prevention of disease, one of the most prevalent diseases in Brazil and the world and closely related to cardiovascular and cerebrovascular events.

\section{Conflict of interest}

The authors declare no conflict of interest.

\section{Funding}

VIGITEL was funding by the Health Surveillance Department at Brazilian Ministry of Health and the present work was financed in part by the Coordenação de Aperfeiçoamento de Pessoal de Nível Superior - Brasil (CAPES) - Finance Code 001.

\section{Authors' contributions}

Santos PC, Costa RM, Streb AR, Del Duca GF, Silva KS, Gerage AM participated in the initial conception of the manuscript. Santos PC, Costa RM, Streb AR conducted data analysis, data interpretation and study writing. Del Duca GF, Silva KS, Gerage AM e DM contributed to the relevant critical review of the manuscript's intellectual content e Malta DC also contributed to the acquisition of the data. All authors approved the version of the work to be published.

\section{Acknowledgments}

The authors would like to thank the Health Surveillance Department at Brazilian Ministry of Health for carrying out the VIGITEL survey and the other VIGITEL 2015 collaborators: Juliano Ribeiro Moreira, Barbara de Sá Menezes Teixeira, Rosângela Durso Perillo, Marta Maria Alves da Silva, Maria Aline Siqueira Santos, Taís Porto Oliveira, Naiane de Brito Francischetto, Paula Carvalho de Freitas, Lucélia Silva Nico, Patrícia Pereira Vasconcelos de Oliveira, Maryane Oliveira Campos.

\section{References}

1. World Health Organization. Global Atlas on Cardiovascular Disease Prevention and Control: Suíça. 2011. [cited 2019 jun 12]. Available from: https://www.who.int/cardiovascular_ diseases/publications/atlas_cvd/en/.

2. Roger VL, Go AS, Lloyd-Jones DM, Benjamin EJ, Berry JD, Borden WB, et al. Heart disease and stroke statistics-2012 update: A report from the American heart association. Circulation. 2012;125(1):e2-220.
3. Mancia G, Fagard R, Narkiewicz K, Redon J, Zanchetti A, Böhm M, et al. 2013 ESH/ESC guidelines for the management of arterial hypertension: The Task Force for the management of arterial hypertension of the European Society of Hypertension (ESH) and of the European Society of Cardiology (ESC). Eur Heart J. 2013;34(28):2159-219.

4. World Health Organization. Cardiovascular Diseases (CVDs). 2017. [cited 2019 jun 14]. Available from: https:// www.who.int/news-room/fact-sheets/detail/cardiovasculardiseases-(cvds).

5. Danaei G, Finucane MM, Lin JK, Singh GM, Paciorek CJ, Cowan MJ, et al. National, regional, and global trends in systolic blood pressure since 1980: Systematic analysis of health examination surveys and epidemiological studies with 786 country-years and $5 \bullet 4$ million participants. Lancet. 2011;377(9765):568-77.

6. Mills KT, Bundy JD, Kelly TN, Reed JE, Kearney PM, Reynolds K, et al. Global Disparities of Hypertension Prevalence and Control: A Systematic Analysis of Population-based Studies from 90 Countries. Physiol Behav. 2017;176(3):139-48.

7. Vedanthan R, Bernabe-Ortiz A, Herasme OI, Joshi R, Lopez-Jaramillo P, Thrift AG, et al. Innovative Approaches to Hypertension Control in Low- and Middle-Income Countries. Cardiol Clin. 2017;35(1):99-115.

8. Radovanovic CAT, dos Santos LA, Carvalho MD, Marcon SS. Arterial Hypertension and other risk factors associated with cardiovascular diseases among adults. Rev Lat Am Enfermagem. 2014;22(4):547-53.

9. Choe KY, Han SY, Gaub P, Shell B, Voisin DL, Knapp BA, et al. High Salt Intake Increases Blood Pressure via BDNFMediated Downregulation of KCC2 and Impaired Baroreflex Inhibition of Vasopressin Neurons. Neuron. 2015;85(3):549-60.

10. Wang H, Zhang X, Zhang J, He Q, Hu R, Wang L, et al. Factors Associated with Prevalence, Awareness, Treatment and Control of Hypertension among Adults in Southern China: A Community-Based, Cross-Sectional Survey. PLoS One. 2013;8(5):e62469.

11. Zatu MC, Van Rooyen JM, Kruger A, Schutte AE. Alcohol intake, hypertension development and mortality in black South Africans. Eur J Prev Cardiol. 2016;23(3):308-15.

12. Bhatt D, Sharma S, Gupta R, Sinha DN, Mehrotra R. Predictors of Hypertension among Nonpregnant Females Attending Health Promotion Clinic with Special Emphasis on Smokeless Tobacco: A Cross-Sectional Study. Biomed Res Int. 2017;2017:8765217.

13. Barreto SM, Passos VMA, Firmo JOA, Guerra HL, Vidigal PG, Lima-Costa MFF. Hypertension and clustering of cardiovascular risk factors in a community in Southeast Brazil: the Bambuí Health and Ageing Study. Arq Bras Cardiol. 2001;77(6):576-81.

14. World Health Organization. Global Health Risks: Mortality and burden of disease attributable to selected major risks: Suíça. 2009. [cited 2019 mar 31]. Available from: https://www.who.int/healthinfo/global_burden_disease/ GlobalHealthRisks_report_full.pdf.

15. Nakanishi N, Li W, Fukuda H, Takatorige T, Suzuki K, Tatara K. Multiple Risk Factor Clustering and Risk of Hypertension in Japanese Male Office Workers. Ind Health. 2003;41(4):327-31.

16. Khanal MK, Mansur Ahmed MSA, Moniruzzaman M, Banik PC, Dhungana RR, Bhandari P, et al. Prevalence and clustering of cardiovascular disease risk factors in rural Nepalese population aged 40-80 years. BMC Public Health. 2018;18(1):677. 
17. Monteiro CA, Moura EC, Jaime PC, Lucca A, Florindo AA, Figueiredo ICR, et al. Monitoramento de fatores de risco para doenças crônicas por entrevistas telefônicas. Surveillance of risk factors for chronic diseases through telephone interviews. Rev Saúde Pública. 2005;39(1):47-57.

18. BRASIL. Ministério da Saúde. Secretaria de Vigilância em Saúde. Departamento de Vigilância de Doenças e Agravos não Transmissíveis e Promoção da Saúde. Vigitel Brasil 2014: vigilância de fatores de risco e proteção para doenças crônicas por inquérito telefônico: estimativas sobre frequência e distribuição sociodemográfica de fatores de risco e proteção para doenças crônicas nas capitais dos 26 estados brasileiros e no Distrito Federal em 2015 / Ministério da Saúde, Secretaria de Vigilância em Saúde, Departamento de Vigilância de Doenças e Agravos não Transmissíveis e Promoção da Saúde. - Brasília: Ministério da Saúde, 2015. [cited 2019 ago 18]. Available from: http://bvsms.saude.gov.br/bvs/publicacoes/ vigitel_brasil_2015.pdf.

19. Ministério da Saúde / Secretaria de Vigilância em Saúde, Departamento de Vigilância de Doenças e Agravos não Transmissíveis e Promoção da Saúde. Vigitel Brazil: Ponderação pelo método rake. 2013. [cited 2020 abr 04]. Available from: https://portalarquivos2.saude.gov.br/images/ pdf/2014/setembro/29/Nota-----pondera----o-Rake.pdf.

20. World Health Organization. A global brief on Hypertension. 2013. [cited 2019 set 10]. Available from: https://www. who.int/cardiovascular_diseases/publications/global_brief_ hypertension/en/.

21. Lee IM, Shiroma EJ, Lobelo F, Puska P,Blair SN, Katzmarzyk PT; Lancet. Physical Activity Series Working Group. Effect of physical inactivity on major non communicable diseases worldwide: an analysis of burden of disease and life expectancy. Lancet. 2012;380(9838):219-29.

22. Schuit AJ, Van Loon AJM, Tijhuis M, Ocké MC. Clustering of lifestyle risk factors in a general adult population. Prev Med. 2002;35(3):219-24.
23. Poortinga W. The prevalence and clustering of four major lifestyle risk factors in an English adult population. Prev Med. 2007;44(2):124-8.

24. Meader N, King K, Moe-Byrne T, Wright K, Graham H, Petticrew $\mathrm{M}$, et al. A systematic review on the clustering and co-occurrence of multiple risk behaviours. BMC Public Health. 2016;16(1):1-9.

25. Barreto IF. Tabaco: a construção das políticas de controle sobre seu consumo no Brasil. Hist. cienc. saude-Manguinhos. 2018;25(3):797-815.

26. Silva DAS, Peres KG, Boing AF, González-Chica DA, Peres MA. Clustering of risk behaviors for chronic noncommunicable diseases: A population-based study in southern Brazil. Prev Med. 2013;56(1):20-4.

27. Del Duca GF, Silva KS, Garcia LMT, Oliveira ESA, Nahas MV. Clustering of unhealthy behaviors in a Brazilian population of industrial workers. Prev Med. 2012;54(34):254-8.

28. Li Y, Feng X, Zhang M, Zhou M, Wang N, Wang L. Clustering of cardiovascular behavioral risk factors and blood pressure among people diagnosed with hypertension: A nationally representative survey in China. Sci Rep. 2016;6:27627.

29. Sallis JF, Bull F, Guthold R, Heath GW, Inoue S, Kelly P, et al. Progress in physical activity over the Olympic quadrennium. Lancet. 2016;388(10051):1325-36.

30. Grucza RA, Sher KJ, Kerr WC, Krauss MJ, Lui CK, $\mathrm{McDowell} \mathrm{YE}$, et al. Trends in Adult Alcohol Use and Binge Drinking in the Early 21st-Century United States: A MetaAnalysis of 6 National Survey Series. Alcohol Clin Exp Res. 2018;42(10):1939-1950.

Recebido: $31 / 01 / 2020$

Aprovado: 07/05/2020

\section{Quote this article as:}

Santos PC, Del Duca GF, Silva KS, Costa RM, Streb AR, AM Gerage et al. Simultaneity of unhealthy behaviors associated with bypertension among Brazilian adults. Rev Bras Ati Fis Saúde. 2019;24:e0100. DOI: 10.12820/rbafs.24e0100 